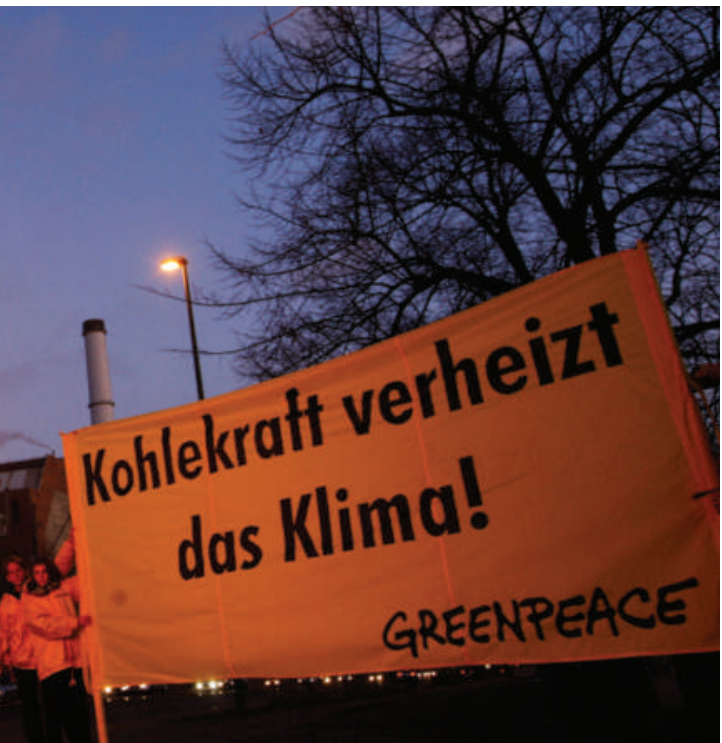

be willing to subscribe to in a new treaty.

Some observers believe that the biggest challenge will be money, particularly in the midst of an economic crisis. Costs for adaptation to climate change in the developing world alone have been estimated at US $\$ 100$ billion annually, and some suggest the figure could be two or three times that amount. The World Bank estimates that establishing a low-carbon economy in developing countries could cost several hundred billion dollars each year.

Money could enable progress on other fronts. Some developing nations have proposed to allow rich countries that cannot sufficiently reduce their emissions to make up the shortfall with cash. Indeed, after blasting the inadequacy of the US climate proposals, India's Ramesh smiles and acknowledges that a deal would be much more likely if the United States were to put, say, $\$ 200$ billion on the table.

Saleemul Huq, who tracks adaptation issues for the London-based International Institute for Environment and Development, says that developed countries will have two more chances to address the issue before Copenhagen (see also Nature doi:10.1038/ news.2009.1019; 2009). The EU finance ministers were scheduled to meet as Nature went to press, and a meeting of the G20 finance ministers is due in early November.

"One expects that they will come back with some kind of offer, and that would then unlock other issues in the negotiations," Huq says. "They will still be wrangling about the amounts, but at least they will go into the process of negotiating. Right now they are posturing, not negotiating." Jeff Tollefson

See Editorial, page 1027, and online at www.nature. com/roadtocopenhagen

\title{
Hwang verdict imminent
}

Despite his research being exposed as fraudulent and unethical almost four years ago, the career of South Korean cloner Woo Suk Hwang has thrived. He has established a research institute, laid claim to a set of human-cloning patents, received a scientific excellence award, published a handful of papers and entered into a collaboration with a powerful provincial government.

Now Hwang faces his biggest hurdle yet: the possibility of jail time. As Nature went to press, a verdict was expected on charges that he knowingly used faked research results to apply for grants, embezzled as much as 2.8 billion Korean won (US\$2.4 million), and purchased human eggs in violation of the country's bioethics law.

The charges relate to two papers in which Hwang claimed to have created stem-cell lines from cloned human embryos, and to have used the technology to develop patient-specific stem cells (W. S. Hwang et al. Science 303, 1669-1674; 2004; and W. S. Hwang et al. Science 308, 1777-1783; 2005).

Both were found to have been fabricated.

In August, at the last of 43 judicial hearings on the affair, prosecutors sought four years in prison for Hwang. It was the end of an epic 40-month trial that saw the chief judge change three times, heard testimonies from more than 60 witnesses and included some bizarre moments such as when Hwang claimed he could not account for some of his funding because he had used it to pay Russian mafia for access to the DNA of a frozen mammoth that he hoped to clone.

Hwang still has powerful supporters. In June, he received an award from the Jang Yeong-sil Memorial Foundation for scientific excellence. In August, the South Korean province of Gyeonggi announced that it planned a collaboration with Hwang to develop transgenic animals able to grow organs for transplantation to humans. And on 12 October, 33 parliamentarians submitted a petition to the Seoul Central District Court Criminal Division pleading for leniency in sentencing Hwang so that he can continue his research without further ado.

Meanwhile, stem-cell science in South Korea has also bounced back from the scandal. In July, the government promised to triple its funding for the field to 120 billion won by 2015 . The government is also putting together a plan to give about 20 top stem-cell projects up to 1 billion won each over two years, with the possibility of twice that amount in a subsequent funding round. In April, the government approved an application by Seoul's Pochon CHA University to carry out human therapeutic cloning experiments.

"The future of stem-cell research is very promising," says Dong-Youn Hwang of the Pochon CHA University. "Many Korean people now realize that stemcell-based therapy is not magic, but only results from hard work, huge investment and continuous support," he adds.

Developmental biologist Kunsoo Rhee of Seoul National University, where Woo Suk Hwang worked until he was dismissed in 2006, says that the increased attention on scientific conduct has had some positive outcomes, including an undergraduate course on misconduct, which began at the university two years ago. "If we have something like [the Hwang case] all the time it would be bad, but once every 10 years - or hopefully only once in our lifetime - it can be a learning experience."

"After Hwang's scandal, Korean biotech is getting more transparent," adds Kyung-Sun Kang of Seoul National University's Adult Stem Cell Research Center. Kang says that although research on embryonic stem cells was difficult for a while, there has been an upsurge in the commercialization of adult stem cells, with several stem-cell therapies now in clinical trials.

If Woo Suk Hwang avoids a prison sentence, he says that he plans to continue his efforts to benefit South Korea by continuing his research on mammalian cloning, and still hopes to vindicate his human-cloning technique.

David Cyranoski 